\title{
Reproductive Biology of Commercially Valuable Squid, Sepioteuthis lessoniana (Lesson, 1830) Taken as By-Catch in a Tropical Trawl Fishery
}

\author{
Vellathi VENKATESAN ${ }^{1 *}$, Santhanam RAJAGOPAL ${ }^{2}$ \\ ${ }^{1}$ Central Marine Fisheries Research Institute, Cochin, 682018, India; venkatcmfri@yahoo.co.in ("corresponding author) \\ ${ }^{2}$ Annamalai University, Centre of Advanced Study in Marine Biology, Faculty of Marine Science, Parangipettai, 608502, India
}

\begin{abstract}
Some aspects of the reproductive characteristics of the commercially important squid Sepioteuthis lessoniana (Lesson, 1830) in the coastal waters of Mandapam, Palk Bay was studied with a view to provide possible management measures in this region. A total of 984 individuals (508 males and 476 females) were collected between April, 2009 to March, 2010. The size of specimens ranged from $40 \mathrm{~mm}$ to $290 \mathrm{~mm}$ in mantle length. Sex ratio was not significantly different $(p>0.05)$ from the expected ratio of 1:1 except for months of July, October and December. Spawning season as revealed by seasonal maturity stages, gonadosomatic index of sexes and nidamental gland length (NGL) and dorsal mantle length (DML) ratio of females, lied between January to June with peak at February. Size at maturity as determined by graphical method was 83.5 for males and 112.5 for females.
\end{abstract}

Keywords: Mandapam waters, Palk Bay, reproductive biology, Sepioteuthis lessoniana

\section{Introduction}

In India, cuttlefishes, squids and octopuses commonly known as cephalopods are principally caught as by-catch from shrimp and fish trawls employed by the trawlers. Squids are an important by-catch in trawl fisheries in Indian waters, forming approximately $42 \%$ of total cephalopods catch (CMFRI, 2010). The main squid species landed are Sepioteuthis lessoniana, Loligo duvaucelii, L. uyii, L. edulis, L. singhalensis, Loliolus investigatoris, Symplectoteuthis oualaniensis and Thysanoteuthis rhombus, of which only the first one is normally available in Palk Bay and Gulf of Mannar waters (Mohamed, 2008).

All squids are semelparous, which means they spawn once in life time and die (Boyle and Rodhouse, 2005), or repeatedly over an extensive period, ranging from a few days to several months (Sauer et al., 1997). Their reproductive output, the spawning strategy and success are critical since these would affect the continuity of the next population in terms of the strength of next generation. Sexual maturation in cephalopods appears to be largely under the influence of a gonadotropic hormone originating from the optic glands (O'Dor and Wells, 1978). Little is known about the spawning seasonality of tropical and subtropical squid and cuttlefish (Jackson and Moltschaniwskyj, 2001)

Species supporting major loliginid fisheries, such as $L$. gahi in the Southwest Atlantic (Guerra and Castro, 2004), and L. duvaucelii in Thailand (Chotiyaputta, 1993) and India (Asokan, 2000), have been studied in relation to their reproductive biology in a view to provide manage- ment measures in their respective regions. In view of the economic importance of the squid fishery in this area (Mandapam, Palk Bay), basic knowledge on the reproductive biology is necessary to provide the biological basis for implementation of possible management measures which aimed at sustainable exploitation of the resource. Except the study of Rao (1954), there was no detailed information regarding reproductive biology of $S$. lessoniana carried out from the Palk Bay water. The aim of the present study were to study some aspects of the reproductive characteristics of this species from the Mandapam area.

\section{Materials and methods}

Random samples of $S$. lessoniana were collected at monthly interval from commercial trawl landings of Mandapam centre (Fig. 1). A total of 984 specimens (508 males and 476 females) were investigated during April 2009 to March 2010. Total weights and dorsal mantle length (DML/ML) were accurately weighed / measured to $0.01 \mathrm{~g}$ and $0.1 \mathrm{~mm}$ respectively in fresh animals. DML values were between $40 \mathrm{~mm}$ and $290 \mathrm{~mm}$ for both sexes. Animals were sexed based on morphological characters. After dissecting, gonads of both sexes were weighed; length (NGL) and weight of the nidamental glands were taken in case of females.

The sex ratio was computed for each month and also for each length group (class size $=10 \mathrm{~mm}$ ). The left $4^{\text {rd }}$ arm was modified into hectocotylised in males only and sex was determined based on this arm. The homogeneity in the distribution of both sexes was tested using the chi 


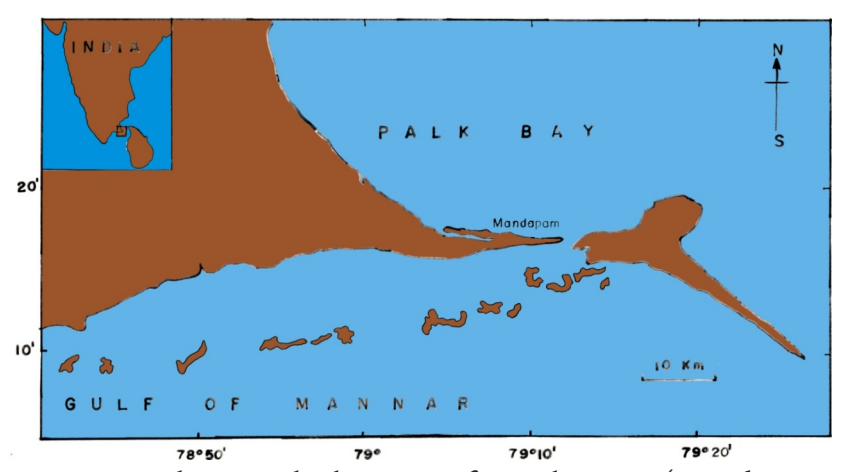

Fig. 1. Map showing the location of sampling site (Mandapam, Palk Bay)

square formula $\left(\chi^{2}=\Sigma(\mathrm{O}-\mathrm{E})^{2} / \mathrm{E}\right.$ where, $\chi^{2}$ - Chi square; $\mathrm{O}$ - Observed frequency; $\mathrm{E}$ - Expected frequency).

The maturity stages of specimens were determined by assessing its internal organ visually (Fig. 2) by following the four point maturity scale developed for squid (Silas, 1985 a). The maturity scale could not be applied to individuals (juvenile) that are not distinguished by sexual characteristics.

The gonad somatic index (GSI) for males and females (Joy, 1989) was calculated (GSI $=100 \mathrm{GW} / \mathrm{BW}$ where, GW- gonad weight; BW- body weight) and NGL/DML ratio for females were also computed for assessing the reproductive status of individuals.

The size at first maturity defined here as the size (using cumulative frequency distribution) at which $50 \%$ of the individuals in the sample size are mature (stage III and IV) and was determined using the graphical methods Udupa (1986)

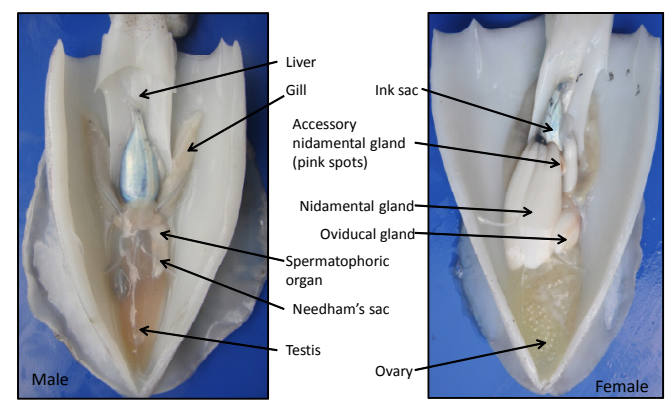

Fig. 2. Mantle cavity of (a) male and (b) female squid S. lessoniana showing the reproductive structures

\section{Results}

\section{Sex ratio}

Analysis of chi square values indicated that the sex ratio was not significantly differ from the expected ratio of 1:1 except for months of July, October and December. This gives mean sex ratio of $1: 1.03$ with a chi square value of 3.54 , which is not significantly different from the expected 1:1 ratio (Tab. 1). Tab. 2 gives the details of the sex ratio with respect to the different size groups. Proportion of males present in the samples was dominant in larger size group. Chi square test results indicated that in smaller size groups; the ratio was not significantly differ from the expected ratio of $1: 1$, whereas in higher size groups; the ratio differs significantly from the expected ratio of 1:1.

\section{Monthly variation in maturity stages}

The occurrence of different maturity stages of gonads was examined throughout the period of study in order to determine the spawning season. Fig. 3 and 4 illustrate the monthly percentage composition of the maturity stages of both the sexes for $S$. lessoniana. Male gonads were observed in mature condition, with spermatophores in Needham's sac, throughout the year indicating a year round reproductive activity.

In female squid, immature ovaries were more during April-June and maximum percentage of mature ovaries were recorded during the months of October - December and June. Spawning/spent animals were observed throughout the study. Occurrence of maturity stages indicate that squid of various stages of maturity occurred in most of the months. It can be thus inferred that $S$. lessoniana has a prolonged breeding season extending from December to July with peak spawning activity during January - March.

\section{Gonado somatic index}

Seasonal variation in mean GSI was pronounced for both sexes (Fig. 5 and 6). Male GSI increased in December and peaked in January, February and March; this coincided with the peak percentage of specimens in spawning condition. This index declined gradually starting from June, and reached its lowest values between July and November. Female index exhibited the gradual increase in November and reached its highest level during December to April, followed almost the same trend as in males; this coincided with the peak incidence of individuals in spawning condi-

Tab. 1. Monthly variation of sex ratio of $S$. lessoniana

\begin{tabular}{ccccccc}
\hline Months & $\begin{array}{c}\text { No. } \\
\text { examined }\end{array}$ & $\begin{array}{c}\text { Male } \\
(\mathrm{M})\end{array}$ & $\begin{array}{c}\text { Female } \\
(\mathrm{F})\end{array}$ & $\begin{array}{c}\text { Sex } \\
\text { ratio }\end{array}$ & $\chi^{2}$ & $p$-value \\
\hline Apr & 53 & 21 & 32 & 1.52 & 2.28 & $<0.05$ \\
\hline May & -- & -- & -- & -- & -- & -- \\
\hline Jun & 107 & 47 & 60 & 1.28 & 1.58 & $<0.05$ \\
\hline Jul & 62 & 46 & 16 & 0.35 & 14.52 & $>0.05$ \\
Aug & 77 & 41 & 36 & 0.88 & 0.32 & $<0.05$ \\
\hline Sep & 163 & 89 & 74 & 0.83 & 1.38 & $<0.05$ \\
\hline Oct & 78 & 27 & 51 & 1.89 & 7.38 & $>0.05$ \\
\hline Nov & 72 & 44 & 28 & 0.64 & 3.56 & $<0.05$ \\
\hline Dec & 87 & 54 & 33 & 0.61 & 5.07 & $>0.05$ \\
\hline Jan & 91 & 49 & 42 & 0.86 & 0.54 & $<0.05$ \\
\hline Feb & 62 & 25 & 37 & 1.48 & 2.32 & $<0.05$ \\
\hline Mar & 132 & 65 & 67 & 1.03 & 0.03 & $<0.05$ \\
\hline
\end{tabular}


16

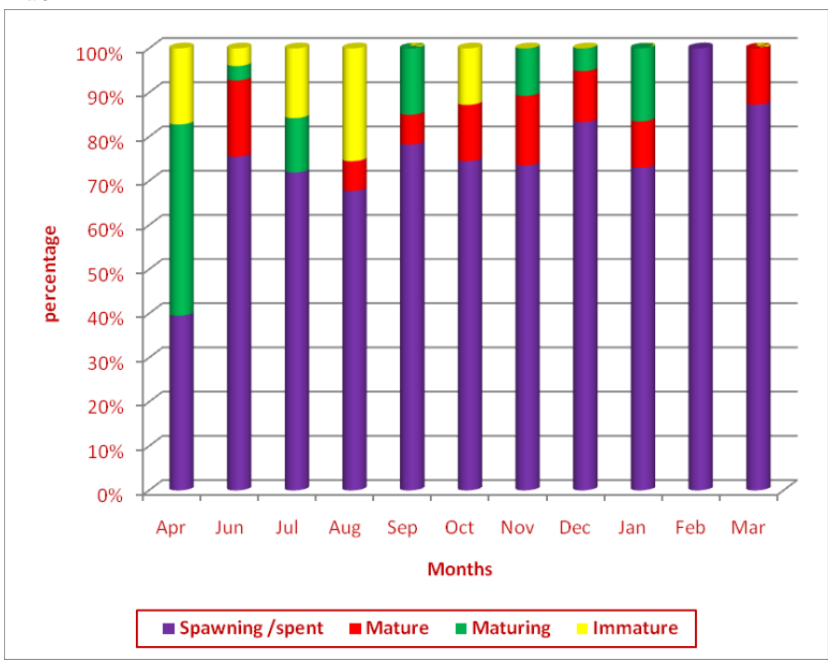

Fig. 3. Monthly stages of maturity of male of S. lessoniana

tions. Mean NGL/DML ratio for females was calculated and mean values are plotted in Fig. 7. NGL/DML ratio showed the similar trend as in female GSI.

\section{Size at first maturity}

To determine size at first maturity, squids were grouped sex wise into $5 \mathrm{~mm}$ size groups and percentage of maturity in each size group was calculated. Size at first maturity of S. lessoniana of both sexes is given in Fig. 8. All the males were immature up to $64.5 \mathrm{~mm}$ ML. In $65.5-79.5 \mathrm{~mm}$ size groups, $41.9 \%$ were mature condition. The percentage matured squids increased gradually from $80.5-110.5$ $\mathrm{mm}$ size groups where $98.6 \%$ of the specimens were ma-

Tab. 2. Sex ratio of S. lessoniana in various length groups

\begin{tabular}{ccccccc}
\hline $\begin{array}{c}\text { Length } \\
\text { groups } \\
(\mathrm{mm})\end{array}$ & $\begin{array}{c}\text { No. } \\
\text { examined }\end{array}$ & $\begin{array}{c}\text { Male } \\
(\mathrm{M})\end{array}$ & $\begin{array}{c}\text { Female } \\
(\mathrm{F})\end{array}$ & $\begin{array}{c}\text { Sex } \\
\text { ratio }\end{array}$ & $\chi^{2}$ & -value \\
\hline $40-49$ & 8 & 4 & 4 & 1 & 0 & $<0.05$ \\
\hline $50-59$ & 12 & 3 & 9 & 3 & 3 & $<0.05$ \\
\hline $60-69$ & 43 & 21 & 22 & 1.05 & 0.02 & $<0.05$ \\
\hline $70-79$ & 44 & 18 & 26 & 1.44 & 1.45 & $<0.05$ \\
\hline $80-89$ & 36 & 19 & 17 & 0.89 & 0.11 & $<0.05$ \\
\hline $90-99$ & 46 & 31 & 15 & 0.48 & 5.57 & $>0.05$ \\
\hline $100-109$ & 66 & 33 & 33 & 1 & 0 & $<0.05$ \\
\hline $110-119$ & 69 & 34 & 35 & 1.03 & 0.01 & $<0.05$ \\
\hline $120-129$ & 63 & 31 & 32 & 1.03 & 0.02 & $<0.05$ \\
\hline $130-139$ & 76 & 39 & 37 & 0.95 & 0.05 & $<0.05$ \\
\hline $140-149$ & 99 & 43 & 56 & 1.3 & 1.71 & $<0.05$ \\
\hline $150-159$ & 87 & 33 & 54 & 1.64 & 5.07 & $>0.05$ \\
$160-169$ & 78 & 32 & 46 & 1.44 & 2.51 & $<0.05$ \\
\hline $170-179$ & 66 & 25 & 41 & 1.64 & 3.88 & $<0.05$ \\
\hline $180-189$ & 47 & 21 & 26 & 1.24 & 0.53 & $<0.05$ \\
\hline $190-199$ & 32 & 21 & 11 & 0.52 & 3.13 & $<0.05$ \\
\hline $200-209$ & 32 & 26 & 6 & 0.23 & 12.5 & $>0.05$ \\
\hline $210-219$ & 26 & 22 & 4 & 0.18 & 12.46 & $>0.05$ \\
\hline $220-229$ & 16 & 15 & 1 & 0.07 & 12.25 & $>0.05$ \\
\hline $230-239$ & 15 & 14 & 1 & 0.07 & 11.27 & $>0.05$ \\
\hline & & & & & & \\
\hline
\end{tabular}

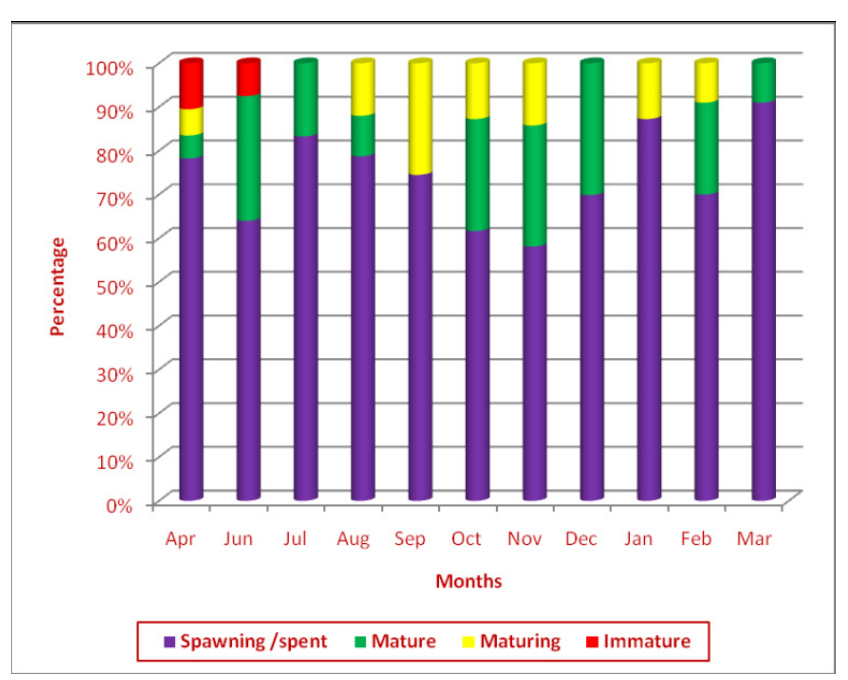

Fig. 4. Monthly stages of maturity of female of $S$. lessoniana

ture and all the specimens above $115.5 \mathrm{~mm} \mathrm{ML}$ were mature. Up to $99.5 \mathrm{~mm} \mathrm{ML}$, all the females were in immature stage. In $100.5-104.5 \mathrm{~mm}$ size groups, only $11.8 \%$ were in mature condition. In 105.5 - $109.5 \mathrm{~mm}$ size class, $29.3 \%$ were found as mature. The percentage matured squids increased suddenly above this size group and in $119.5 \mathrm{~mm}$ size class the percentages of immature stage is very less and $68.9 \%$ were in mature group. The percentage matured squids gradually increased further and at $125.5 \mathrm{~mm}$ size group, $98.5 \%$ were mature. The size at first maturity was estimated $83.5 \mathrm{~mm} \mathrm{ML}$ for males and $112.5 \mathrm{~mm} \mathrm{ML}$ for females.

\section{Discussion}

This squid species exhibited reproductive trait typical of many loliginids. In general, the period of peak reproductive activity for $S$. lessoniana was during post-monsoon months, that is, January to March.

\section{Sex ratio}

The sex ratio was not significantly differing in most of the months in this study except July, October and December (Tab. 1). The similar observation was reported for squid L. duvaucelii (Sang, 2007). On the contrary, Silas et al., (1985 b) studying in the same species of Gulf of Mannar, India reported that males were dominant in most of the months except January to February; their dominant value for males may be a result of selectively sampling larger animals of commercial catch. Analysis of sex ratio in relation to size groups showed that it is not significantly differ in smaller size groups compared to larger groups ( $>200 \mathrm{~mm}$ ML) (Tab. 2). This may also be a result of selectively sampling larger animals of commercial catch. The variation in the ratio may also be due to various factors like migration associated with sexual maturation and spawning; feeding behavior related to reproduction, post spawning mortality and difference in the growth in both sexes (Mangold, 1983 a). 


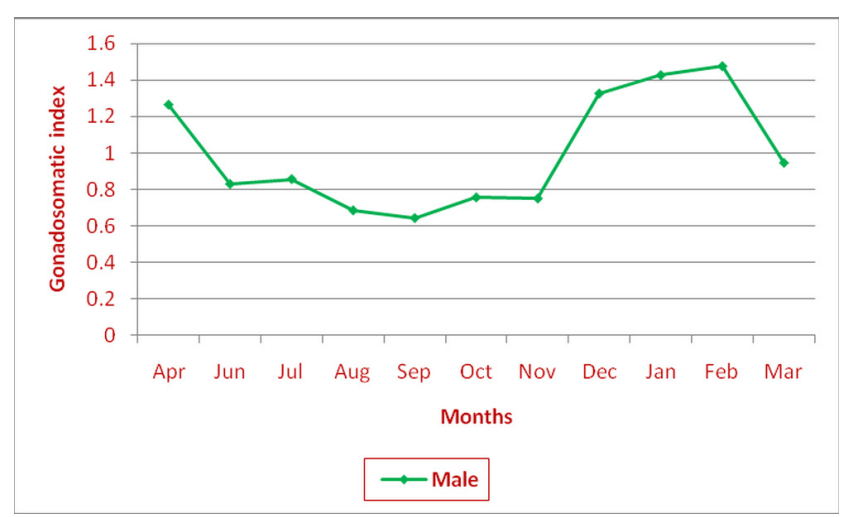

Fig. 5. Monthly variation in mean GSI for male S. lessoniana

\section{Sexual maturation}

The presence of mature ova in the ovaries is an indication of its spawning activity. Mature reproductive organs were observed throughout the year (Fig. 3 and 4) in this study. These results indicated that this species spawns almost throughout the year. From data, it can be seen that reproductive organs in a stage of fullness were observed during the months of December-February indicating a peak spawning activity of this species at Mandapam waters during these months. This conclusion is supported by the fact that mature females dominated in the samples taken in December (55\%), January (67.43\%) and February $(70.28 \%)$. Spawning of S. lessoniana as indicated by the presence of mature gonads was observed during the post-monsoon months with peak periods, January to June or July. The reproductive organs were observed to be fully, partially or wholly exhausted in the months of May, June, July and August months. The squid $L$. duvaucelii spawns throughout the year along both the coasts, peak spawning has been observed during post monsoon months (Mohamed, 1993).

In the present study, sexual maturation of $S$. lessonaina occurred from December to February and the spawning period from January to June or July. The same observation has been reported for S. lessoniana (Rao, 1954). Mhitu et al. (2001) observed that the season of sexual maturation of S. lessoniana around Chwaka Bay, Tanzania was from March to June with a peak in May. Segawa (1987)

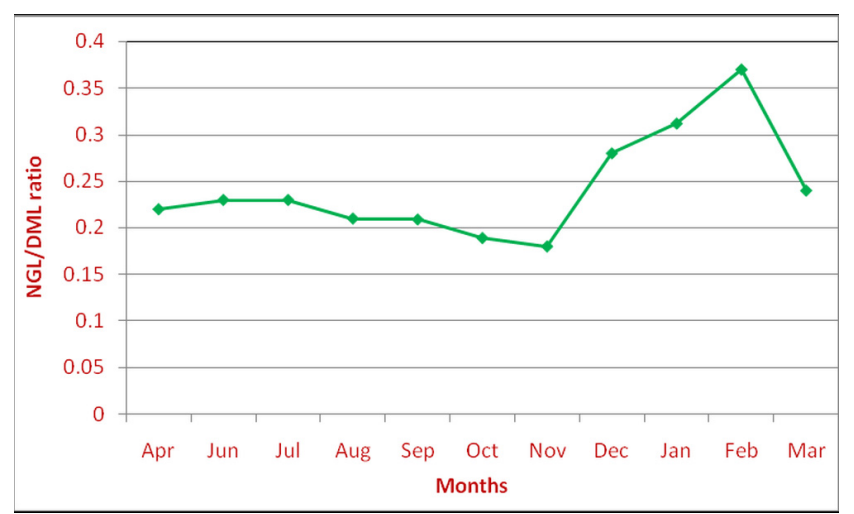

Fig. 7. Monthly variation in NGL/DML ratio for female $S$. lessoniana

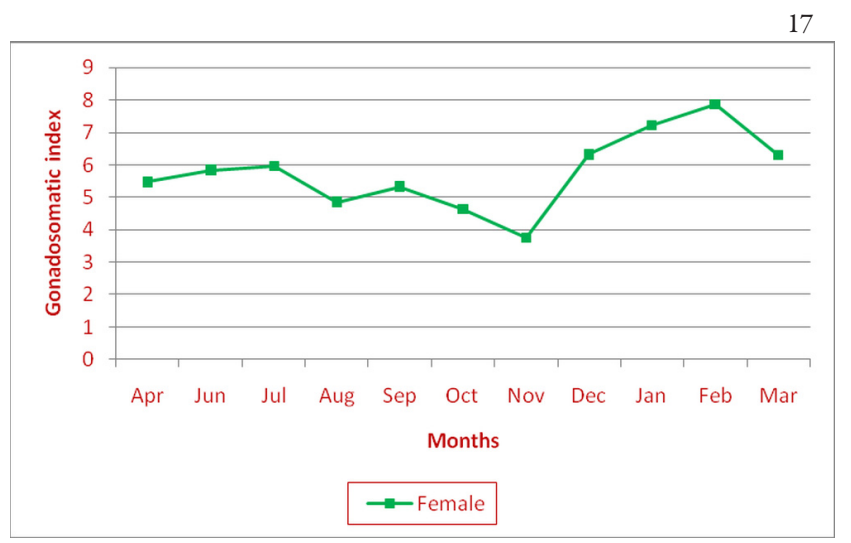

Fig. 6. Monthly variation in mean GSI for female S. lessoniana reported on the same species in Japan that sexual maturation takes place from May to mid or late June. Kilada and Riad (2010) reported on the L. duvaucelii squid in Red Sea, Egypt that the spawning activity was associated with the relative decline in total somatic weight with maturation. As in many marine invertebrates, sexual maturation and reproduction are the most energy-intense periods of the cephalopod life cycle. Somatic production exceeds gamete production during early life, but is later exceeded by gamete production, which eventually dominates tissue growth (Rodhouse, 1998). Prolonged spawning periods are characteristic of tropical and subtropical species of fishes which exist in lower latitudes, while comparatively shorter spawning seasons characterise the higher latitude temperate species (O'Dor and Wells, 1987). In tropical waters, where variations in sea temperature and food supply are not so well marked, these two factors do not seem to act as trigger stimuli for breeding (Qasim, 1973). However, annual change in temperature and salinity may affect the coastal fishes to some extent in their breeding season.

In the present study, the variations of GSI during different months were used to identify the spawning season of this species. A higher proportion of adults appeared in the study sites during the proposed spawning seasons by evidence of high GSI, higher percentage of mature individuals (maturity III and IV) and high incidence of mated female. The results of this study showed that the GSI values of females increased from mid of November and reached

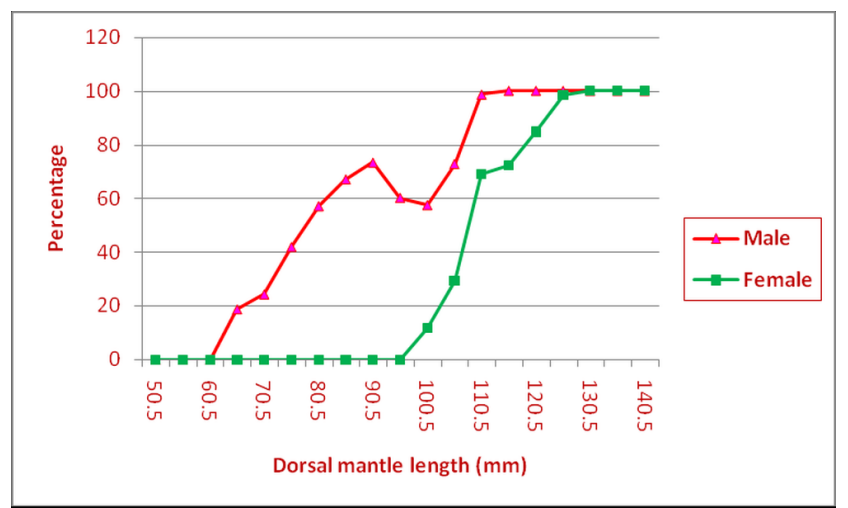

Fig. 8. Size at first maturity of males and females of $S$. lessoniana 
18

a maximum value in February. The high GSI values during these months indicated that the maximum gonadial activity had taken place, indicating a probable spawning period of the species. Low GSI values during July to November showed reduction in the reproductive activity. In males also similar seasonal change was observed in GSI values as female. The ratios GSI and NGL/DML correlated positively with maturation and spawning in S. lessoniana. The similar observation has been noted for $S$. lessoniana (Sivashanthini et al., 2010; Mhitu et al., 2001) and Loligo forbesi (Boyle and Ngoile, 1993). Results of GSI and NGL/DML are important for determining the reproductive cycle of S. lessoniana. Boyle and Ngoile (1993) have shown that the GSI is the best index in assessing maturation and identifying spawning period in L. forbesi. The reproductive cycle is reflected by pronounced variations in gonadal size which depends on animal size and stage of gonadal development (de Vlaming et al., 1982). The gonad and the digestive gland that accumulate the necessary resources for egg production as well as oviduct gland that acts as a reservoir for sperms; increases in size with sexual maturation. This explains why maximum values of the indices occur when there is maximum reproductive activity (Mangold, 1983 b). Moreover, females may invest more energy resources in reproduction for oocytes production than males do for sperm production (Ho et al., 2004)

\section{Size at first maturity}

Size at first maturity indicates the size at which half of the population mature and ready for reproduction. The size at first maturity in this area obtained by graphical method was $83.5 \mathrm{~mm}$ and $112.5 \mathrm{~mm}$ DML for males and females respectively. Size at first maturity values for males and females of $S$. lessoniana obtained in the present study agree with those reported by Rao (1954). Rao (1954) reported that males of $S$. Lessoniana reach sexual maturity within the size range of $67.5 \mathrm{~mm}-112.5 \mathrm{~mm}$ and females within $102.5-112.5 \mathrm{~mm}$. Mhitu et al. (2001) reported on the same species in Tanzania that the size at first maturity values for males and females were 102.5 and $112.5 \mathrm{~mm}$ which were higher for male compared to present values. How ever, in both cases; male mature at smaller size compared to females. As temperature is closely related to the growth of squid (Hatfield, 2000), such geographical separation and difference in temperature may have resulted in the different sizes of S. lessoniana in the different regions. Silas et al. (1985 b) studying in the maturity of squids and cuttlefishes of Indian waters reported that in squid $L$. duvaucelii, males attained sexual maturity earlier than females and in all species spawning is prolonged. Present study reveals that males are more precocious in reproduction than females, reaching sexual maturity at an early size, as in the case of most of the cephalopods. Early maturation and year round maturity of males ensures high rate mating success of the species.

\section{Conclusions}

S. lessoniana is one of the commercially important squid distributed in the Palk Bay and Gulf of Mannar region of India (Rao, 1954). The reproductive characteristics of $S$. lessoniana presents scenario of seasonal changes in sex ratio, matury stages, GSI, size at maturity and thereby spawning period can be predicted. Mature reproductive organs were observed throughout the year. Peak spawning of the squid in Mandapam waters is post monsoon months i.e. January to June. As with all commercial species of cephalopods especially squids, little is known concerning the impact of fishing on matured and spawning adults, whose life cycle is known to be very short. If overexploitation occurs, spawning adults could be decreased and subsequently recruitment overfishing occurred or reproductive capacity of population reduced. Such situation can be managed by setting restrictions on number of fishing units or ban on trawl fishing during the peak spawning periods. Hence, the present study would definitely lead to formulate a effective fishery management measures so as to ensure the sustainable fishery.

\section{Acknowledgements}

Authors would like to thank the Director, CMFRI and the Dean, Centre of Advanced study in marine biology, Annamalai University for facilities and encouragement. Gratitude is expressed to the anonymous referees for their constructive comments on the manuscript. Authors would like to express their sincere thanks to the editor for publishing this manuscript in the journal in time.

\section{References}

Asokan PK (2000). Biology and fishery of cephalopods (Mollusca: Cephalopoda)along the Malabar Coast, Zoological Institute, University of Calicut, India.

Boyle PR, Ngoile MAK (1993). Assessment of maturity state and seasonality of reproduction in Loligo forbesi (Cephalopoda: Loliginidae) from Scottish waters, In: Okutani T, O’Dor RK, Kubodera T (Eds.). Recent Advances in Fisheries Biology. Tokyo, Tokai University Press.

Boyle PR, Rodhouse PG (2005). Cephalopods: Ecology and Fisheries. Blackwell Science Ltd. Oxford.

Chotiyaputta C (1993). A survey on diversity and distribution of juvenile squids in the inner and western Gulf of Thailand. Thai Mar Fish Res Bull 4:19-36.

CMFRI (2010). Annual Report 2009-2010. Central Marine Fisheries Research Institute, Cochin, India.

Guerra A, Castro BG (1994). Reproductive-somatic relationships in Loligo gabi (Cephalopoda: Loliginidae) from the Falkland Islands. Antarctic Sci 6(2):175-178.

Ho JD, Moltschaniwskyj NA, Carter CG (2004). The effect of variability in growth on somatic condition and reproductive status in the southern calamari Sepioteuthis australis. Mar 
Freshwater Res 55:423-428.

Hatfield EMC (2000). Do some like it hot? Temperature as a possible determinant of variability in the growth of the $\mathrm{Pa}$ tagonian squid, Loligo gahi (Cephalopoda: Loliginidae). Fish Res 47:27-40.

Jackson GD, Moltschaniwskyj NA (2001). Temporal variation in growth rates and reproductive parameters in the small near-shore tropical squid Loliolus noctiluca; is cooler better? Mar Ecol Prog Ser 218:167-177.

Joy JB (1989). The fishery biology of ommastrephid squid in Shetland waters. Msc Thesis, University of Aberdeen.

Kilada R, Riad R (2010). Seasonal reproduction biology of Uroteuthis duvauceli in northern red sea, Egypt. J shellfish Res 29(4):781 -791.

Mangold K (1983 a). Eledone moschata. In: Boyle PR (Ed.) Cephalopod Life Cycles, Vol I., Academic Press, London.

Mangold K (1983 b). Food, feeding and growth in cephalopods. Mem Natl Mus Victoria Melbourne 44:81-93.

Mhitu H, Mgaya Y, Ngoile M (2001).Western Indian Ocean Marine Science Association, Zanzibar (Tanzania) and Institute of Marine Sciences, Zanzibar (Tanzania) University of Dar es Salaam. In: Richmond MD, Francis J (Eds.). Growth and reproduction of the Big fin squid, Sepioteuthis lessoniana in the Coastal Waters of Zanzibar, IMS/WIOMSA, Zanzibar, Tanzania.

Mohamed KS (2008). Molluscan fisheries of India. In: Vivekanandan K, Jayasankar J (Eds.).Winter school on impact of climate change on Indian marine fisheries, Part I, CMFRI publication, Central Marine Fisheries Research Institute, Kochi, India.

Mohamed KS (1993). Spawning congregations of Indian squid Loligo duvaucelii (Cephalopoda: Loliginidae) in the Arabian Sea off Mangalore and Malpe. Indian J Mar Sci 22:172-175.

O’Dor RK, Wells MJ (1978). Reproduction versus somatic growth: hormonal control in Octopus vulgaris. J Exp Biol 77:15-31.

O’Dor R K, Wells MJ (1987). Energy and nutrient flow. In: Boyle PR (Eds.). Cephalopod life cycles, Vol II Comparative reviews, Academic Press Inc. (London) Ltd.

Qasim SZ (1973). An appraisal of the studies on maturation and spawning in marine teleosts from Indian waters. Ind J Fish 20: 351-371.

Rao KV (1954). Biology and fishery of Palk bay squid Sepioteuthis arctipinnis Gould. Ind J Fish 1: 37-66.

Rodhouse PG (1998). Physiological progenesis in cephalopod molluscs. Biol Bull 195:17-20.

Sang CK (2007). Reproductive biology and ecology of the loliginid squid, Uroteuthis (Photololigo) duvauceli (ORBIGNY, 1835), in Hong Kong waters, PhD. Thesis, University of Hong Kong.

Sauer WHH, Koberts MJ, Lipinski M, Smale MJ, Hanlon KT, Webber DM, O'Dor KK (1997). Choreography of the squid's “nuptial dance”. Biol. Bull 192:203-207.

Segawa S (1987). Life history of the oval squid, Sepioteuthis lessoniana in Kominato and adjacent waters, Central Honshu, Japan. J Tokyo Univ Fish 74:67-105.

Silas EG (1985 a). Cephalopod fisheries of India - An introduction to the subject with methodologies adopted for the study. In: Silas EG (Ed.). Cephalopod bionomics, fisheries and resources of the EEZ of India. Bull Cent Mar Fish Res Inst 37:1-4.

Silas EG, Rao KS, Sarvesan R, Nair KP, Vidyasagar K, Meiyappan MM, SastriYA, Rao BN (1985 b). Some aspects of the biology of squids. In: Silas EG (Ed.). Cephalopod bionomics, fisheries and resources of the EEZ of India. Bull Cent Mar Fish Res Inst 37:38-48.

Sivashanthini K, Thulasitha WS, Charles GA (2010). Reproductive characteristics of squid Sepioteuthis lessoniana (Lesson, 1830) from the northern coast of Sri Lanka. J Fish Aquat Sci 5(1):12-22.

Udupa KS (1986). Statistical method of estimating the size at first maturity in fishes. Fish byte 4(2):8-10. 